\section{ANNALS OF THE UNIVERSITY OF CRAIOVA}

\author{
Series: $\checkmark$ Biology \\ $\checkmark$ Horticulture \\ $\checkmark$ Food products processing \\ technology \\ $\checkmark$ Environmental engineering
}

Vol. XXVI (LXII) - 2021

\title{
IDENTIFICATION OF THREATS OF AMPHIBIANS AND REPTILES PROTECTED SPECIES IN THE SITE ROSCI0045 THE JIU CORRIDOR
}

\author{
Ciupeanu Călugăru Eleonora Daniela1* ${ }^{1 *}$ Țucă Ovidiu Andrei ${ }^{1}$, Stan Cătălin ${ }^{1}$ \\ ${ }_{1}^{*}$ University of Craiova, Faculty of Horticulture, Craiova \\ * Correspondence author. E-mail: ciupeanudaniela@gmail.com
}

Keywords: threats, amphibians, reptiles

\begin{abstract}
This paper presents the results of the research on threats of amphibians and reptiles protected species in the site ROSCI0045 the Jiu corridor. In the site ROSCI0045 the Jiu corridor there have been identified 4 species of amphibians and reptiles: Bombina variegata (Yellow-bellied toad), Bombina bombina (European fire-bellied toad),Triturus dobrogicus (Danube new), Emys orbicularis (European pond tortoise). From the analysis of threats of amphibians and reptiles protected species in the site ROSCI0045 The Jiu Corridor it was found that for every endangered spercies there are several threats.
\end{abstract}

\section{INTRODUCTION}

Protected areas are considered an essential strategy for habitat and species conservation (Geldmann, J. et al.,2013).

Management effectiveness reports suggest only $22 \%$ of protected areas have 'sound management'(Leverington, F. et al 2010), experts estimate that only half of all tropical reserves are effective (Laurance, W. F. et al. 2012) and human pressures are increasing in Latin American, African and Asian protected areas (Geldmann, J. et al., 2014). Declines in animal and plant abundance have been documented inside protected areas (Craigie, I. D. et al, 2010) and in many countries the effectiveness of protection is being compromised by external pressures and inadequate government support.

Protected areas are essential tools to achieve international biodiversity targets (Watson, J. E. M., et al, 2014). However, anthropogenic climate change will induce a fundamental redistribution of life on earth that affects the effectiveness of Protected areas (Johnston, A. et al 2013) as well as ecosystem functioning and human welfare (Pecl, G. T. et al. ,2017). Species shift and resize their ranges under climate change, mainly migrating poleward and towards higher elevation as they track suitable habitats (Scheffers, B. R. et al.,2016).

The site ROSCI0045 The Jiu Corridor takes place mainly on the administrative territory of Dolj county $-73.76 \%$ of the site area, as well as in Gorj county $-25.07 \%$ of the site area; very small areas are found in Olt counties $-0.67 \%$ of the site area and Mehedinți $0.29 \%$ of the site area. The total area of the natural area of community interest ROSCI0045 Jiu Corridor is 71,452 ha, being arranged on a length of about $150 \mathrm{~km}$ from the Getic Subcarpathians to the Danube. 
Within the limits of the ROSCI0045 Jiu Corridor site, there are two Natura 2000 sites: ROSPA0023 Jiu-Danube Confluence, ROSPA0010 Bistret and five nature reserves: 2,390 Bucovăț fossil site, 2,391 Drănic fossil site, 2,399 Cleanov, 2,448 Gârbov IV fossil site. Zăval. At landscape level in ROSCI0045 Jiu Corridor there are ecosystems of aquatic and marshy wetlands, open areas of xeric and alluvial meadows, hayfields and forest ecosystems.

\section{MATERIAL AND METHODS}

The study on the threats of amphibians and reptiles was performed by two methods, depending on the type of vegetation present in the investigated area:

- In the case of habitats with uniform structure, the observations were made in surveys of $250 \mathrm{~m}^{2}$ arranged along transects of $1000 \mathrm{~m}$ in length covering a territory of $2000 \mathrm{~m}^{2}$. The investigation of the control area of $2000 \mathrm{~m}^{2}$ had an average duration of 20-25 minutes, period in which the presence or absence of individuals, the number of active specimens, the type of habitat, the presence of hiding places, the presence of possible predators were recorded.

- In the case of linear habitats (forest edge, river banks) the observations were made along some paths parallel to the longitudinal axis of the respective habitat. The established transects had a length of $500 \mathrm{~m}$ and $1500 \mathrm{~m}$.

\section{RESULTS AND DISCUSSIONS}

The studies were carried out during April to September 2020.

The amphibians had the optimal period of inventory in the spring, when they migrated to the breeding sites and a lot of individuals were reported populating aquatic habitats, the capture being made using the net with round metal frame and telescopic arm, through selective captures (capture direct of the observed specimens) noting the species, the number of individuals.

Herpetofauna, mainly amphibian species, due to adaptations and fine responses to the actions of environmental factors, can be indicators of habitat quality. The study of these groups is beneficial not only to determine the value of some biodiversity indicators, but also to establish the conservation status of the habitats in which they are found.

Amphibian and reptile species inventoried and evaluated at the Jiu Corridor site: Bombina variegata (Yellow bellied toad), Bombina bombina (European fire bellied toad), Triturus dobrogicus (Danube newt), Emys orbicularis (European pond tortoise).

Bombina variegata Status of the species: Almost endangered species according to the Red Book of Vertebrates in Romania, 2005, species of least concern, according to IUCN 3.1.

Bombina bombina Status of the species: Almost endangered species (Red Book of Vertebrates in Romania, 2005). Species of Least Concern according to IUCN 3.1

Emys orbicularis Species status: Vulnerable species, according to the Red Book of Vertebrates in Romania 2005. Low Risk / Near Threatened species, according to IUCN 3.1.

Triturus dobrogicus Species status: Vulnerable species, according to the Red Book of Vertebrates in Romania 2005. Low Risk / Near Threatened species, according to IUCN 3.1.. 
Threats of amphibians and reptiles protected species in the site ROSCI0045

The Jiu Corridor

\begin{tabular}{|c|c|c|}
\hline Species & $\begin{array}{l}\text { Threat } \\
\text { code }\end{array}$ & Threat description \\
\hline \multirow{6}{*}{$\begin{array}{l}\text { Bombina } \\
\text { variegata }\end{array}$} & D01.02 & Roads, highways \\
\hline & $\mathrm{H} 01$ & $\begin{array}{l}\text { Surface water pollution - limnic, terrestrial, marine } \\
\text { and brackish. }\end{array}$ \\
\hline & K01.03 & Draining \\
\hline & J02.01.02 & $\begin{array}{l}\text { Recovery of land from the sea, estuaries or } \\
\text { swamps }\end{array}$ \\
\hline & J02.01.03 & $\begin{array}{l}\text { Filling ditches, ditches, ponds, ponds, swamps or } \\
\text { pits }\end{array}$ \\
\hline & 103.01 & Genetic pollution - animals \\
\hline \multirow{7}{*}{$\begin{array}{l}\text { Bombina } \\
\text { bombina }\end{array}$} & A04 & Grazing \\
\hline & D01.02 & Roads, highways \\
\hline & K01.03 & Draining \\
\hline & $\mathrm{H} 01$ & $\begin{array}{l}\text { Surface water pollution - limnic, terrestrial, marine } \\
\text { and brackish. }\end{array}$ \\
\hline & J02.01.02 & Recovering of the lands from sea, estuaries or pits \\
\hline & J02.01.03 & $\begin{array}{l}\text { Filling ditches, ditches, ponds, ponds, swamps or } \\
\text { pits }\end{array}$ \\
\hline & 103.01 & Genetic pollution - animals \\
\hline \multirow{5}{*}{$\begin{array}{l}\text { Triturus } \\
\text { dobrogicus }\end{array}$} & A04.01 & Intensive grazing \\
\hline & E03.01 & $\begin{array}{l}\text { Storage of household waste / waste from } \\
\text { recreational facilities }\end{array}$ \\
\hline & J02.01.02 & $\begin{array}{l}\text { Recovery of land from the sea, estuaries or } \\
\text { swamps }\end{array}$ \\
\hline & J02.01.03 & $\begin{array}{l}\text { Filling ditches, ditches, ponds, ponds, swamps or } \\
\text { pits }\end{array}$ \\
\hline & J02.05.03 & Modification of standing waters \\
\hline \multirow{6}{*}{$\begin{array}{l}\text { Emys } \\
\text { orbicularis }\end{array}$} & F03.02.09 & Other forms of fauna taking / extracting \\
\hline & K01.03 & Draining \\
\hline & $\mathrm{H} 01$ & $\begin{array}{l}\text { Surface water pollution - limnic, terrestrial, marine } \\
\text { and brackish. }\end{array}$ \\
\hline & J02.01.03 & $\begin{array}{l}\text { Filling ditches, ditches, ponds, ponds, swamps or } \\
\text { pits }\end{array}$ \\
\hline & K03.05 & Antagonism arising from the introduction of species \\
\hline & J03.01 & Reduction or loss of specific habitat characteristics \\
\hline
\end{tabular}




\section{CONCLUSIONS}

From the analysis of threats of amphibians and reptiles protected species in the site ROSCI0045 The Jiu Corridor it was found that for every endangered spercies there are several threats.

According to our data, the most common threats are:

Filling ditches, ditches, ponds, ponds, swamps or pits (J02.01.03);

Surface water pollution - limnic, terrestrial, marine and brackish (H01);

Recovery of land from the sea, estuaries or swamps (J02.01.02);

Draining (K01.03)

Roads, highways (D01.02.).

\section{REFERENCES}

Craigie, I. D., Baillie, J. E. M., Balmford, A., Carbone, C., Collen, B. Green, R. E., Hutton, J. M.. 2010. Large mammal population declines in Africa's protected areas. Biol. Conserv. 143, 2221-2228.

Geldmann, J., Barnes M., Coad L., Craigie I. D., Hockings M., Burges N.D. 2013. Effectiveness of terrestrial protected areas in reducing habitat loss and population declines. Biol. Conserv. 161, 230-238.

Geldmann, J., Joppa, L. N. \& Burgess, N. D. 2014. Mapping change in human pressure globally on land and within protected areas. Conserv. Biol. 28, 1604-1616.

Johnston, A., Ausden M, Dodd AM, Bradbury RB, Chamberlain DE, Jiguet F, Pearce-Higgins J.W. 2013. Observed and predicted effects of climate change on species abundance in protected areas. Nat. Clim. Chang. 3, 1055-1061.

Leverington, F., Costa, K. L., Pavese, H., Lisle, A. \& Hockings, M. A. 2010. global analysis of protected area management effectiveness. Env. Manag. 46, 685-698.

Laurance, W. F., Useche, D. C., Rendeiro J. 2012. Averting biodiversity collapse in tropical forest protected areas. Nature 489, 290-294.

Pecl, G. T. et al. Biodiversity redistribution under climate change: impacts on ecosystems and human well-being. Science 355, eaai9214 (2017).

Scheffers, B. R. et al.The broad footprint of climate change from genes to biomes to people. Science 354, aaf7671 (2016).

Watson, J. E. M., Dudley, N., Segan, D. B. \& Hockings, M. The performance and potential of protected areas. Nature 515, 67-73 (2014). 